\title{
Antimicrobial policy interventions in food animal production in South East Asia
}

\author{
Flavie Goutard and colleagues call for concerted multisectoral measures through stronger \\ policies to combat antimicrobial resistance
}

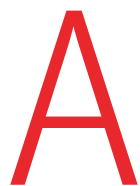

ntibiotics and other antimicrobial agents are widely used in food animal production for disease prevention and treatment in animals, to contain disease spread, to prevent contamination of the food chain, and to increase productivity. ${ }^{1}$ However, their wide use in humans and animals leads to the emergence of antimicrobial resistance, a general term that encompasses antibiotic resistance. ${ }^{2}$ In September 2016, the United Nations recognised the global rise of antimicrobial resistance as a threat to health and human development. ${ }^{3}$

Antimicrobial resistance will increase infectious disease outbreaks, slowing down livestock productivity and disrupting international trade. Recent projections estimated that by 2050 global livestock production would fall by $3 \%$ to $8 \%$ each year, resulting in the decline in the annual global gross domestic product of $1.1 \%-3.8 \%$. Because of higher disease incidence, these falls will affect low income countries more severely, with a predicted rise of 6.2 to 18.7 million in the number of extremely poor people by $2030 .{ }^{4}$ The UN has called for a limit on the overuse of

\section{KEY MESSAGES}

- Key policies for tackling antimicrobial resistance are still lacking in many countries in the South East Asia region, including veterinary surveillance of antimicrobial resistance and antimicrobial use, raising awareness among professionals and farmers, and strengthening the national drug regulatory authorities in the animal health sector

- Although bans on over-the-counter antibiotics and use of antibiotics as growth promoters have been introduced in many countries, enforcement remains a challenge

- Further evidence is needed to understand local barriers and to propose viable, policy driven solutions

- The World Health Organization, World Organisation for Animal Health, and the Food and Agriculture Organization have important roles in identifying best practices in the region to support development of national policies antimicrobial agents, including in animals, but an evaluation of the national animal health systems of about 130 countries, performed by the World Organisation for Animal Health (OIE) using its performance veterinary services pathway tool, showed that more than 110 of them do not yet have appropriate legislation to regulate the import, manufacture, distribution, and use of antimicrobial agents. Even where legislation does exist and is enforced, antibiotics continue to be freely circulated as common goods, and in many countries they are often counterfeited. ${ }^{5}$

Several countries in the region produce meat and aquaculture products for the global market. ${ }^{6}$ The World Health Organization South East Asia region (SEAR: Bangladesh, Bhutan, Democratic People's Republic of Korea, India, Indonesia, Maldives, Myanmar, Nepal, Sri Lanka, Thailand, Timor-Leste) has developed intensive farming systems, leading to the rising consumption of fertilisers, antibiotics, and pesticides, of which many farmers have limited technical knowledge. The lack or weakness of regulations, adequate policies, and implementation of standards for antibiotic use in the food animal sector, together with low standards of biosecurity, hygiene, and sanitation, have accelerated the emergence and dissemination of antibiotic resistance. ${ }^{27}$ We have determined the challenges and requirements for policy interventions to combat antimicrobial resistance in food animal production in each of the SEAR countries, with a focus on antibiotic production and marketing, use, and monitoring of resistance.

\section{Methods}

We reviewed several databases (PubMed, Science Direct, MEDLINE, LISTA, Web of Sciences, Scopus, and Google Scholar) to search for official documents, in English or French, published after 2010. We consulted the legislative and policy database (Faolex: http://faolex.fao.org/) of the Food and Agriculture Organization of the United Nations (FAO) and made contact with the FAO and OIE national focal points for veterinary products. We retrieved documents from eight countries, including 16 legal documents and 11 policies, related strategies, and action plans (table 1). For each document we extracted information on the topic (drug and medicine production and marketing, drug and medicine use, antibiotic resistance surveillance and monitoring); the competent authority in charge; the type of document (policy or legal document); the objective(s); the key components and limitations. These results were cross checked with additional information on policy implementation and law enforcement found in other non-official documents. ${ }^{28910}$ Specific recommendations are based on the reference guides published by WHO, OIE, and FAO. ${ }^{11-13}$

\section{Food animal sector: trends and challenges of} antibiotic use

Over recent decades, profound changes in food production and feeding regimens have had a major effect on the use of antibiotics in livestock and aquaculture farms. Most SEAR countries have experienced considerable growth in population, combined with improved living standards for part of the population. In India, the national diet has radically changed, with increased meat consumption among the young urban generation. ${ }^{14}$ This growing demand for animal proteins has resulted in intensive breeding of pigs, poultry, and fish, with the routine use of antibiotics as growth promoters. Meanwhile, these countries still face high levels of infectious disease, with a lack of health advice and guidance in veterinary care. This, together with weak regulations surrounding the sale of antibiotics and surveillance, has led to the emergence, maintenance, and spread of antibiotic resistance. ${ }^{4}$

Policy related best practices and global challenges for their implementation

The region is recognising that antimicrobial resistance issues are critical and has moved to develop sound and comprehensive policies to tackle the problem. These policies are often in line with international standards (Codex, see box 1; OIE, see table 2) and trade partner requirements. However, the regulatory framework is often outdated and does not allow governments to implement and monitor the course of action defined in their policies. Furthermore, some of the objectives of these policies remain elusive and are clearly unattainable in the socioeconomic context. 


\begin{tabular}{|c|c|c|c|c|c|}
\hline Document title & Year & Type & Development/monitoring & Use & Monitoring \\
\hline \multicolumn{6}{|l|}{ Bangladesh } \\
\hline Fish feed and animal feed act & 2010 & L & - & Yes & - \\
\hline National livestock development policy & 2007 & $\mathrm{P}$ & - & Yes & - \\
\hline National strategy for antimicrobial resistance containment (ARC) & 2011 & $\mathrm{P}$ & - & Yes & Yes \\
\hline The drug (control) ordinance & 1982 & $\mathrm{~L}$ & Yes & - & - \\
\hline \multicolumn{6}{|l|}{ Bhutan } \\
\hline Medicines rules and regulation & 2012 & L & Yes & Yes & - \\
\hline National action plan on antimicrobial resistance (draft) & 2015 & $P$ & - & Yes & Yes \\
\hline National antimicrobial policy (draft) & 2015 & $\mathrm{P}$ & - & Yes & Yes \\
\hline \multicolumn{6}{|l|}{ India } \\
\hline Advisory on use of antibiotics in food producing animals & 2014 & $\mathrm{P}$ & - & Yes & - \\
\hline Bureau of Indian Standards, poultry feed specification, 5th revision 1374:2007 & 2007 & $\mathrm{P}$ & - & Yes & - \\
\hline Food safety and standards (contaminants, toxins, residues) regulations & 2011 & $\mathrm{~L}$ & - & Yes & - \\
\hline National livestock policy & 2013 & $\mathrm{P}$ & - & Yes & - \\
\hline National policy for containment of antimicrobial resistance & 2011 & $\mathrm{P}$ & Yes & Yes & - \\
\hline \multicolumn{6}{|l|}{ Indonesia } \\
\hline Law No 18 on husbandry and animal health & 2009 & L & - & Yes & - \\
\hline Manual for prime method of animal drugs manufacturing & 1999 & $\mathrm{P}$ & Yes & - & - \\
\hline Regulation of the head of the agency of drug and food control no 27 & 2013 & L & Yes & - & - \\
\hline Regulation of the head of the agency of drug and food control no 28 & 2013 & L & Yes & Yes & - \\
\hline Regulation of the minister of marine affairs and fishery on fish medication & 2012 & L & Yes & - & - \\
\hline Terms and procedures for the issuance of animal medicine business permit & 2009 & $\mathrm{~L}$ & Yes & - & - \\
\hline \multicolumn{6}{|l|}{ Myanmar } \\
\hline Fisheries law directive 9.96 on general product standard & 1996 & $\mathrm{~L}$ & - & Yes & - \\
\hline \multicolumn{6}{|l|}{ Nepal } \\
\hline Drug act & 1978 & $\mathrm{~L}$ & Yes & - & - \\
\hline \multicolumn{6}{|l|}{ Sri Lanka } \\
\hline Animal Diseases Act No 59 & 1992 & L & Yes & - & - \\
\hline \multicolumn{6}{|l|}{ Thailand } \\
\hline Code of practice for control of the use of veterinary drugs & 2009 & L & - & Yes & - \\
\hline Drug ACT B.E.2510 (A.C. 1967) and its amendment & 2001 & L & Yes & - & - \\
\hline
\end{tabular}

No documents were retrieved for Timor-Leste, Korea, and Maldives. $L=$ legislation; $\mathrm{P}=$ policies.

Box 1: Codex texts on foodborne antimicrobial resistance related best practices for resistance containment in food animal sectors-Codex Alimentarius Commission ${ }^{15}$ Guidelines for risk analysis of foodborne antimicrobial resistance (CAC/GL 77-2011, adopted 2011)

These guidelines aim to

- Provide science-based guidance on processes and methodology for risk analysis and its application to foodborne AMR [antimicrobial resistance] related to non-human use of antimicrobial agents

- Assess the risk to human health associated with the presence in food and animal feed, including aquaculture, and the transmission through food and animal feed, of AMR microorganisms and determinants, to provide advice on appropriate risk management activities to reduce such risk

- Address the risk associated with different sectors of antimicrobial agent use such as veterinary applications, plant protection or food processing

Code of practice to minimise and contain antimicrobial resistance (CAC /RCP 61-2005, adopted 2005)

This code provides recommendations to regulatory authorities and operators involved in the authorisation, manufacture, sale and supply, prescription, and use of antimicrobials in food producing people, in order to prevent or reduce the selection of antimicrobial resistant microorganisms in humans and animals.

These two texts, together with specific standards of importance to animal production, have supported the development of the Global Action Plan on Antimicrobial Resistance (adopted in May 2015), developed by WHO in collaboration with $\mathrm{FAO}$ and OIE.

\section{Antibiotic production and marketing}

All SEAR countries have sound legal requirements that establish a framework for the quality of drugs used in food animals (table 3). However, official documents do not specifically target antibiotic production and marketing, and requirements for manufacturing and licensing are poorly described. Good manufacturing practices, as well as quality assurance and control, are compulsory in several countries, although only Thailand seems fully able to carry out official checks at every level of the manufacture and distribution of veterinary medicines. Finally, the circulation of counterfeit and substandard antibiotics is poorly dealt with; control legislation (inspections) should not target solely farmers but should include each level of the drug marketing chain. ${ }^{16}$

\section{Antibiotic use}

Regulations on antibiotics in animal feed (for growth promotion or therapeutic use) and the promotion of rational antibiotic use in healthcare and veterinary settings 


\begin{tabular}{|c|c|c|}
\hline Chapter & Guideline & Version \\
\hline \multicolumn{3}{|c|}{ Terrestrial Animal Health Code } \\
\hline Chapter 6.7 & Harmonisation of national antimicrobial resistance surveillance and monitoring programmes & Revision adopted in 2012 \\
\hline Chapter 6.8 & Monitoring of the quantities and usage patterns of antimicrobial agents used in food producing animals & Revision adopted in 2012 \\
\hline Chapter 6.9 & Responsible and prudent use of antimicrobial agents in veterinary medicine & Revision adopted in 2012 \\
\hline Chapter 6.10 & Risk analysis for antimicrobial resistance arising from the use of antimicrobials in animals & Revision adopted in 2014 \\
\hline \multicolumn{3}{|c|}{ Manual of Diagnostic Tests and Vaccines for Terrestrial Animals } \\
\hline Chapter 3.1 & Laboratory methodologies for bacterial antimicrobial susceptibility testing & Current version adopted in May 2012 \\
\hline \multicolumn{3}{|c|}{ Aquatic Animal Health Code } \\
\hline Chapter 6.2 & Principles for responsible and prudent use of antimicrobial agents in aquatic animals & Adopted in 2011 \\
\hline Chapter 6.3 & Monitoring of the quantities and usage patterns of antimicrobial agents used in aquatic animals & Adopted in 2012 \\
\hline Chapter 6.4 & $\begin{array}{l}\text { Development and harmonisation of national antimicrobial resistance surveillance and monitoring } \\
\text { programmes for aquatic animals }\end{array}$ & Adopted in 2012 \\
\hline Chapter 6.5 & Risk analysis for antimicrobial resistance arising from the use of antimicrobial agents in aquatic animals & Adopted in 2015 \\
\hline \multicolumn{3}{|c|}{ Listof antimicrobial agents of veterinary importance } \\
\hline & OIE List of antimicrobial agents of veterinary importance & Revision adopted in 2015 \\
\hline
\end{tabular}

are clearly emerging as priorities for the region. Many countries have already developed policies to ban all use of antibiotics as growth promoters or feed additives, but few yet have the capacity to ensure their implementation (table 4). Policy interventions focus on good practices among health professionals and users, prescriber awareness, and disease prevention and diagnostics, while research on alternatives is overlooked.

\section{Surveillance of antibiotic resistance and monitoring of use}

While recognised as essential in providing the necessary data to fight effectively against antibiotic resistance, surveillance in the food animal sector is at a preliminary stage of development in the region (table 5). Most of the updated documents for surveillance of antibiotic use and antibiotic resistance concentrate only on humans, without considering the animal health sector. Ideally, policies should drive the development of surveillance of the use of antibiotics for terrestrial and aquatic animal health (and plant health), on resistance in clinical isolates from diseased animals, and in commensal and zoonotic bacteria hosted by food producing animals.

\section{Priority actions for best practice policies at regional level}

At the time of writing, all but one country in the region has developed and finalised a national action plan for the containment of antimicrobial resistance in line with the global action plan endorsed by the World Health Assembly in 2015. ${ }^{11}$ Currently, only two countries have had their national action plan endorsed by the highest level of the government. Here, we outline priority actions for regions to design and implement.

\section{Coordinated regional collaboration for better} food and health security

Priority should be placed on strengthening the regional One Health tripartite partnership (FAO, OIE, and WHO), establishing an antimicrobial resistance regional sec- retariat to focus on changes in policy and practices expected at country level. Its main contribution would be to provide a mechanism that facilitates and empowers multisectoral collaboration to combat antibiotic resistance in food animal production. A synergistic approach through a joint regional action plan and continuous communication between regional partners would have a trickle-down effect on SEAR nations. Joint understanding of risks, activities, and recommendations issued by the regional tripartite partnership would drive the organisations' country offices and their respective national counterparts to communicate, exchange, and collaborate.

A regional secretariat could organise the joint monitoring of progress towards implementation of a national action plan, promote best practices on policies, and provide evidence to deal with country specific barriers and challenges concerning policy enforcement. Actions would enable emphasis to be placed on best practices within policies, with the rules and

\begin{tabular}{|c|c|c|c|}
\hline Topic & Main findings/objectives & Gaps identified & Country specific features \\
\hline General & $\begin{array}{l}\text { Existence of official documents framing antimicrobial } \\
\text { production and marketing in } 7 \text { countries ( } 4 \text { policy documents } \\
\text { and } 11 \text { legal instruments) } \\
\text { Joint documents for human and veterinary sectors, issued by } \\
\text { the public health authorities }\end{array}$ & $\begin{array}{l}\text { Antibiotic management poorly addressed as a } \\
\text { specific issue } \\
\text { Legislation outdated regarding the emerging } \\
\text { issue of antibiotic resistance } \\
\text { Inadequacy between policy interventions and } \\
\text { available legal instruments } \\
\text { Drugs management mainly addressed in human } \\
\text { sector }\end{array}$ & $\begin{array}{l}\text { India: specific document dealing with antibiotic } \\
\text { management (human drugs) } \\
\text { Indonesia, Thailand: specific documents for } \\
\text { veterinary drugs } \\
\text { Licensing requirements more or less strict } \\
\text { depending on the country }\end{array}$ \\
\hline $\begin{array}{l}\text { Drug } \\
\text { commercialisation }\end{array}$ & $\begin{array}{l}\text { Mandatory registration and authorisation } \\
\text { Administrative and quality requirements for authorisation, } \\
\text { Authorisation cancellation or suspension conditions, } \\
\text { Active list for illegal substances }\end{array}$ & $\begin{array}{l}\text { Licensing criteria and procedure poorly } \\
\text { described }\end{array}$ & $\begin{array}{l}\text { Nepal, Bangladesh: science based assessment } \\
\text { of drugs before introduction to market }\end{array}$ \\
\hline $\begin{array}{l}\text { Drug production } \\
\text { and manufacture }\end{array}$ & $\begin{array}{l}\text { Compulsory registration for companies, mandatory } \\
\text { implementation and compliance with good manufacturing } \\
\text { practice, quality assurance and control }\end{array}$ & $\begin{array}{l}\text { Official control measures carried out by } \\
\text { competent authorities not commonly addressed }\end{array}$ & $\begin{array}{l}\text { Bhutan, Bangladesh, India, Thailand: provisions } \\
\text { for inspections of manufacturers }\end{array}$ \\
\hline $\begin{array}{l}\text { Drug distribution, } \\
\text { sale, and storage }\end{array}$ & $\begin{array}{l}\text { Mandatory authorisation for business operators } \\
\text { Mandatory compliance with quality and ethical requirements } \\
\text { Quality assessment, licensing of veterinary drugs } \\
\text { Specific requirement for importation and exportation } \\
\text { Assessment of veterinary drug quality before being put on } \\
\text { the market }\end{array}$ & $\begin{array}{l}\text { Official control measures carried out by } \\
\text { competent authorities not commonly addressed }\end{array}$ & $\begin{array}{l}\text { Bhutan, Bangladesh, India, Thailand: provisions } \\
\text { for inspections of sellers }\end{array}$ \\
\hline
\end{tabular}




\begin{tabular}{|c|c|c|c|}
\hline Topic & Main findings/objectives & Gaps identified & Country specific features \\
\hline General & $\begin{array}{l}\text { Existence of official documents framing } \\
\text { antimicrobial use in } 7 \text { countries ( } 9 \text { policy } \\
\text { documents and } 7 \text { legal instruments) } \\
\text { Documents in line with international standards } \\
\text { and trade partner requirements }\end{array}$ & $\begin{array}{l}\text { Inadequacy between policy interventions } \\
\text { and available legal instruments } \\
\text { Disproportionate national policy } \\
\text { objectives regarding the local } \\
\text { socioeconomic context }\end{array}$ & $\begin{array}{l}\text { India, Nepal, Bhutan: national roadmaps to ban non- } \\
\text { therapeutic use of antibiotics in feed but no regulatory } \\
\text { framework for implementation }\end{array}$ \\
\hline $\begin{array}{l}\text { Appropriate and prudent } \\
\text { use of antibiotics }\end{array}$ & $\begin{array}{l}\text { Development of good pharmacist practices } \\
\text { Ban on over-the-counter antibiotics } \\
\text { Development of standard treatment guidelines } \\
\text { Promotion of AST before prescription } \\
\text { Licensing of veterinary pharmacists } \\
\text { Education and awareness of sellers and users }\end{array}$ & $\begin{array}{l}\text { Policy interventions focusing on: } \\
\text { good practices, users and prescribers' } \\
\text { awareness, disease prevention and } \\
\text { spread } \\
\text { Research of new antibiotics and } \\
\text { alternatives is poorly addressed }\end{array}$ & $\begin{array}{l}\text { Indonesia, Thailand: Code of practices for control of veterinary } \\
\text { drugs use (in line with Codex) } \\
\text { Bangladesh, Bhutan, India, Thailand, and Nepal: intersectoral } \\
\text { policies to contain AMR. } \\
\text { India: regulation for judicious use by veterinarians, but no } \\
\text { provisions for implementation and monitoring }\end{array}$ \\
\hline $\begin{array}{l}\text { Regulation of veterinary } \\
\text { medicines and medicated } \\
\text { feed usage }\end{array}$ & $\begin{array}{l}\text { Prohibition on use of antibiotics in feed as growth } \\
\text { promoter } \\
\text { Control enforcement for irrational and non- } \\
\text { therapeutic/subtherapeutic use } \\
\text { Improvement of labelling and traceability } \\
\text { Ban on certain antibiotics critical to human health }\end{array}$ & $\begin{array}{l}\text { Antibiotics still used as growth promoters } \\
\text { or in animal feed for therapeutic use } \\
\text { Lack of official controls to ensure law } \\
\text { enforcement }\end{array}$ & $\begin{array}{l}\text { Sri Lanka, Maldives: ban of all antibiotics as growth promoters } \\
\text { and in medicated feed } \\
\text { Thailand: ban of all antibiotics as growth promoters, total } \\
\text { prohibition of medicated feed in aquaculture, regular official } \\
\text { controls on use } \\
\text { Bangladesh: ban on antibiotics as feed additive } \\
\text { Indonesia, India, Thailand: restriction on the use of antibiotics } \\
\text { intended for human treatment }\end{array}$ \\
\hline
\end{tabular}

AMR=antimicrobial resistance; $A S T=$ antimicrobial susceptibility testing.

legislation rooted in a sound evidence base that is sufficiently flexible to accommodate different contexts. ${ }^{17}$

\section{One Health approach: the way forward}

Combating antibiotic resistance is a complex process in which interventions in a single sector cannot be effective in tackling the problem as a whole. Integrated approaches, which identify the roles and relative importance of each compartment (human, animal, and environment), are key to understanding and combating antibiotic resistance. Above all, an integrated policy is required and could be operated under the One Health umbrella. As resistant organisms exist in humans, animals, food, and the environment-and the main driver of this resistance is antimicrobial use $-\mathrm{a}$ One Health conceptual framework for surveillance and control can be promoted. ${ }^{18}$ Moreover, in a region such as SEAR consisting of many and varied socioeconomic environments, policies should be context dependent and based on economic data, to avoid a negative effect on vulnerable populations and social inequity. Within the region, a One Health approach has been used for some policy decisions (table 4, table 5). For example, documents covering drug production and marketing are often common to human and veterinary sectors, and several countries are developing their national action plans by including multiple sectors.

\section{Increase antibiotic resistance surveillance} and monitoring of use

Surveillance that generates reliable data is essential for sound global strategies and public health actions to contain antibiotic resistance and is urgently needed to improve policy development in SEAR. ${ }^{1920}$ Veterinary services are trying to stretch their resources and capacities beyond the ongoing surveillance of transboundary animal diseases to include antibiotic resistance surveillance, which requires a mainly active form of surveillance. There are various approaches to surveillance: drug resistance of pathogenic or commensal bacteria, antibiotic use for disease treatment, and non-therapeutic use. Understanding what each approach entails will allow the coun- tries to prioritise and eventually help shape policies.

One priority action for the region should be to set-up an integrated surveillance system for drug resistant pathogens, together with a harmonised monitoring system of antibiotic use. The standardisation of data sharing and data collection methods and antibiotic resistance testing, between sectors and countries, should enable each government to implement early effective control measures and to monitor the effectiveness of their policies.

\section{Sharing standards for antibiotic use in animal} food production

Since the introduction of the global action plan on antimicrobial resistance, there has been an international agreement to ban antibiotics as growth promoters in the absence of risk analysis. ${ }^{11}$ Several SEAR countries have already banned antibiotic additives in feed. However, food safety standards used for export products are often higher than those for products intended only for local consumption,

\begin{tabular}{|c|c|c|c|}
\hline Topic & Main findings & Gaps identified & Country specific features \\
\hline General & $\begin{array}{l}\text { Existence of official documents framing AMR or } \\
\text { monitoring of use in } 2 \text { countries ( } 4 \text { policy documents) } \\
\text { Development of documents in line with international } \\
\text { standards (OIE, European regulation) }\end{array}$ & $\begin{array}{l}\text { Topic poorly addressed in official documents } \\
\text { No legal framework to implement the } \\
\text { monitoring objectives when they exist } \\
\text { Lack of cross-sectoral approach in the } \\
\text { updated documents }\end{array}$ & $\begin{array}{l}\text { Bangladesh: development of a national strategy to } \\
\text { contain AMR, including monitoring of resistance and use } \\
\text { Bhutan: draft of integrated surveillance system, in line } \\
\text { with the One Health concept }\end{array}$ \\
\hline AMU monitoring & $\begin{array}{l}\text { Monitoring use and prescribing patterns,- } \\
\text { Assessment of non-therapeutic use in veterinary sector, } \\
\text { Monitoring and evaluation of impact of promotion on } \\
\text { consumption, } \\
\text { Data dissemination to users and prescribers }\end{array}$ & & $\begin{array}{l}\text { Thailand: project developing a policy for monitoring use } \\
\text { India: monitoring of AMR in food animals not yet part of } \\
\text { the national policy on AMR containment. }\end{array}$ \\
\hline ABR surveillance & $\begin{array}{l}\text { Appropriate laboratory capabilities and networking } \\
\text { Development of surveillance protocol } \\
\text { Harmonised AST results reporting system } \\
\text { Prioritisation of bacteria to be monitored } \\
\text { Dissemination of data to stakeholders } \\
\text { Development of a national strains repository }\end{array}$ & & $\begin{array}{l}\text { Thailand: development of a national veterinary } \\
\text { surveillance system for AMR in line with European Union } \\
\text { and OIE requirements but no legal frameworkyet } \\
\text { Nepal: AMR monitoring of animal samples along AMR } \\
\text { surveillance in hospitals }\end{array}$ \\
\hline
\end{tabular}

$A B R=$ antibiotic resistance; $A M R=$ antimicrobial resistance; $A M U=$ antimicrobial use; $A S T=$ antimicrobial susceptibility testing. 
which may be poorly enforced. WHO, OIE, and FAO should support SEAR countries to achieve a total ban on antibiotics for growth promotion by developing measures (biosecurity, farming practices, access to diagnostics, alternatives to antibiotics) based on cost effectiveness studies to preserve farmers' productivity. ${ }^{421}$ Initiatives to include feed industries and to enhance consumer awareness should be promoted.

Meanwhile, monitoring of antibiotic use in food animals should be enforced to detect any increase in animal diseases and to avoid farmers reaching for poor quality antibiotics. Particular attention should be given to the potential effect of new or changed regulatory policies on producers and consumers. ${ }^{17}$ The tripartite alliance could propose standardised assessment of benefits, costs, and effectiveness of reforms, to ensure the development of tailored solutions taking into account specific political, economic, and social factors. $^{22}$

\section{Understanding pathways of antibiotic resistance transmission and drivers of antibiotic use}

Risk analysis, as recommended by the Codex Alimentarius and OIE guidelines, ${ }^{121315}$ is an essential tool to evaluate the risk to human health of antimicrobial resistance transmission from animal feed, to identify risk mitigation strategies, and to communicate on the complexity of this risk and the actions to be taken. However, risk analyses mainly focus on the risk of introducing new veterinary drugs on to national markets. Critical data on risk factors for the emergence and transmission of resistance and pathways of transmission of resistant pathogens or resistance genomes (foods, environments, contacts) are still fragmented. WHO, OIE, and FAO have an important role in providing more examples of risk analysis studies to assess the potential effect of the emergence and transmission of antimicrobial resistance on animal, human, and environmental health, including technical support to deal with risk management options, stakeholders communication, and the perception of risk by end users. Educational efforts for providers-for example, veterinarians and farmers-must be continuous, and appropriate materials and effective communication strategies must be developed. ${ }^{23}$

\section{Conclusion}

SEAR is lagging behind other parts of the world regarding the introduction of policies to combat antibiotic resistance, including surveillance, training of professionals and farmers, and the establishment of independent national drug regulatory authorities. Given the political and economic context, many countries have been unable to enforce policies that are in place, including bans on over-the-counter drugs and growth promoters. The reasons for this include low awareness, competing priorities and costs of policy, and a limited understanding of the relation between resistance in animals, humans, and the environment. Tackling all these issues will lay a solid ground for policy and its enforcement. The One Health approach, driven by WHO, OIE, and FAO, will facilitate the development of global actions across sectors, while recognising specific environmental constraints of each country in the region. ${ }^{17}$

Contributors and sources: SV conceived the article. FLG wrote the first draft. CC, FLG, and FR did the systematic literature review. All the authors contributed to the article. FLG is guarantor. This work was commissioned by the WHO Regional Office of South-East Asia using the UK government's Fleming Fund. The authors alone are responsible for the views expressed in this article, which does not necessarily represent the views, decisions, or policies of the institutions with which the authors are affiliated

Competing interests: We have read and understood BMJ policy on declaration of interests and have no relevant interests to declare.

Provenance and peer review: Commissioned; externally peer reviewed.

This article is one of a series commissioned by The $B M$ J based on an idea from WHO SEARO. The BM retained full editorial control over external peer review, editing, and publication. Open access fees are funded by the WHO SEARO.

Flavie Luce Goutard, senior epidemiologist ${ }^{12}$ Marion Bordier, PhD candidate

Clémentine Calba, research assistant ${ }^{1}$

Elisabeth Erlacher-Vindel, head of science and new technologies department ${ }^{3}$

Delfy Góchez, chargée de mission

Katinka de Balogh, senior officer ${ }^{4}$

Carolyn Benigno, antimicrobial projects coordinator ${ }^{4}$ Wantanee Kalpravidh, regional manager ${ }^{4}$

Francois Roger, director ${ }^{12}$

Sirenda Vong, regional technical lead, antimicrobial resistance

${ }^{1}$ CIRAD, UMR ASTRE, F-34398 Montpellier, France

${ }^{2}$ Kasetsart University, 10900 Bangkok, Thailand ${ }^{3}$ World Organisation for Animal Health (OIE), Paris, France

${ }^{4}$ Food and Agriculture Organization of the United Nations, Regional Office for Asia and the Pacific, Bangkok, Thailand

${ }^{5}$ World Health Organization, Regional Office for South East Asia, New Delhi, India

Correspondence to: FL Goutard flavie.goutard@cirad.fr

Hao H, Cheng G, Iqbal Z, et al. Benefits and risks of antimicrobial use in food-producing animals. Front Microbiol 2014;5:288. doi:10.3389/ fmicb.2014.00288

Chuanchuen R, Pariyotorn P, Siriwattanachai K, et al. REVIEW of the literature on antimicrobial resistance in zoonotic bacteria from livestock in East, South and Southeast Asia. Bangkok, Thailand: FAO Regional Office for Asia and the Pacific 2014. http://cdn.aphca.org/dmdocuments/ REP_AMR_141022_c.pdf
United Nations News Centre. At UN, global leaders commit to act on antimicrobial resistance. 2016.http://www.un.org/apps/news/story. asp?NewsID=55011\#.V-kXivRsIPA

4 World Bank Group. Drug resistant infections: a threat to our economic future. The World Bank 2016. http://pubdocs.worldbank.org/ en/689381474641399486/1701381-AMR-LabReport-Web.pdf.

OIE. Risks associated with the use of antimicrobials in animals worldwide: OIE- World Organisation for Animal Health. http://www.oie.int/en/for-themedia/editorials/detail/article/risks-associatedwith-the-use-of-antimicrobials-in-animalsworldwide/.

6 Dey MM, Rab MA, Jahan KM, et al. Food safety standards and regulatory measures: implications for selected fish exporting Asian countries. Aquac Econ Manag 2005;9:217-36. doi:10.1080/13657300590967450.

7 Hoelzer K, Wong N, Thomas J, Talkington K, Jungman E, Coukell A. Antimicrobial drug use in foodproducing animals and associated human health risks: what, and how strong, is the evidence?BMC Vet Res 2017;13:211. doi:10.1186/s12917-017 1131-3

8 FAO. Proceedings of the international workshop on the use of antimicrobials in livestock production and antimicrobial resistance. Sri Lanka: FAORAP, 2012. http://www.aphca.org/Events/36th_APHCA Session/Papers/Country\%20Report_Lao\%20 PDR\%20F.pdf

9 Thamlikitkul V. Thailand AMR containment operational actions 2012-2016. Thailand 2015. https://www.reactgroup.org/wp-content/ uploads/2016/10/Antibiotic-Smart-Use-projectcase-study.pdf

10 Archawakulathep A, Kim CTT, Meunsene D, et al. Perspectives on antimicrobial resistance in livestock and livestock products in ASEAN countries. Thai I Vet Med 2014;44:5-13

11 WHO. Global action plan on antimicrobial resistance. Published Online First: 2015. http://apps.who.int/ iris/handle/10665/193736

12 World Organisation for Animal Health (OIE). Antimicrobials OIE, 2017. http://www.oie.int/ en/our-scientific-expertise/veterinary-products/ antimicrobials/.

13 Food and Agriculture Organisation, World Health Organization, World Organisation for Animal Health (OIE), eds. Joint FAO/WHO/OIE expert meeting on critically important antimicrobials FAO, 2008.

14 Laxminarayan R, Chaudhury RR. Antibiotic resistance in India: drivers and opportunities for action. PLOS Med 2016;13:e1001974. doi:10.1371/journal. pmed.1001974

15 FAO / WHO Codex Alimentarius. Codex texts on foodborne antimicrobial resistance. 2015. http:// www.fao.org/3/a-i4296t.pdf

16 Grace D. Review of evidence on antimicrobial resistance and animal agriculture in developing countries. Evidence on demand. 2015. https://www. gov.uk/dfid-research-outputs/review-of-evidence-onantimicrobial-resistance-and-animal-agriculture-indeveloping-countries-201309.

17 Dar OA, Hasan R, Schlundt J, et al. Exploring the evidence base for national and regional policy interventions to combat resistance. Lancet 2016;387:285-95 doi:10.1016/S0140-6736(15)00520-6

18 Queenan K, Häsler B, Rushton J. A One Health approach to antimicrobial resistance surveillance: is there a business case for it? Int J Antimicrob Agents 2016:48:422-7. doi:10.1016/i. ijantimicag.2016.06.014

19 Codex Alimentarius Commission. Joint FAO/ WHO food standards programme: Codex work on antimicrobial resistance. FAO/WHO, 2016. http:// www.fao.org/fao-who-codexalimentarius/sh-proxy/ en/?lnk=1\&url=https\%253A\%252F\%252Fworkspa ce.fao.org\%252Fsites\%252Fcodex\%252FMeetings \%252FCX-701-39\%252FWD\%252Fcac39_12e.pdf.

20 World Health Organization, ed. Antimicrobial resistance: global report on surveillance. WHO, 2014 
21 Founou LL, Founou RC, Essack SY. Antibiotic resistance in the food chain: a developing country-perspective. Front Microbiol 2016;7:1881. doi:10.3389/ fmicb.2016.01881
22 Kirkpatrick C, Parker D. Regulatory impact assessment and regulatory governance in developing countries. Public Adm Dev 2004;24:333-44. doi:10.1002/pad.310.

23 Léger D, Deckert A, Gow S, et al. The Canadian Integrated Program for Antimicrobial Resistance
Surveillance: an approach to building collaboration for a voluntary farm surveillance framework. Épidémiologie Santé Anim, 2011.

Cite this as: $B M / 2017 ; 358: j 3544$

http://dx.doi.org/10.1136/bmj.j3544
崩

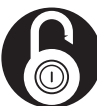

\section{OPEN ACCESS}

This an open access article distributed under the terms of the Creative Commons Attribution-non-commercial IGO License (https:// creativecommons.org/licenses/by-nc/3.0/igo/), which permits use, distribution, and reproduction for non-commercial purposes in any medium, provided the original work is properly cited. In any reproduction of this article there should not be any suggestion that WHO or this article endorse any specific organisation or products. The use of the WHO logo is not permitted. This notice should be preserved along with the article's original URL. 